\title{
運動関連脊䯣電位と中枢性・ 末梢性の運動関連電気現象について
}

\section{1. はじめに}

過去数年間、まだ記録法が確立されていない運 動関連脊髄電位の表皮上記録が可能かどらかを検 討してきた。最近、体動等のアーティファクトも しくは筋電図によるものではないといえる電位を 上肢自発性運動において頸椎部皮虚上から記録す ることができた。この電位の起源が脊髄であるか どらかは今のところ不明であるけれども、起源が 脊髄であることを期待して「脊髄電位」の語を表 題拈よび文中において使用したことを批わりし ておきたい。

運動関連脊䯣電位の記録を思い立った動機は、 約 10 年前に運動の準備・開始と関連があると考之 られる表面筋電図の変化現象を見いだして以降の 研究の中で生じた。ここでは運動関連脊髄電位の ほかに、随意運動発現の準備と関連があると思わ れる表面笳電図波形の変化およびこの変化現象と 運動関連眇電位の関係についても述べさせていた だく。

\section{2. 随意運動に先行する持続性筋放電の変化}

2.1 持続性筋放電の消失々その意義 ${ }^{1)}$

弱い持続性筋放電を保った状態から随意に急激 な動作を行った際、動作を起す相動性筋放電に先 行して持続性放電の消失が起る。猪飼 ${ }^{2)}$ によって 報告されたこの現象は動作前 silent period (PS P) と呼ばれている。この現象は四肢筋においてょ く研究され、反動動作や相反性神経支配によるも のではなく、上位中枢性の抑制現象であって脊䯣 全体の同時抑制によるものと仮定されている。

平成 1 年 8 月 2 日受付

* 製品科学研究所基礎人間工学部生理情報工学課

テ305つくば市東 1-1-4
この泀か運動神経の持続性活動から相動性活動へ の興奮切替に帰されるとも考えられている。 PSP の機能的意義は動作の敏速な発現 ${ }^{6)}$ および巧みさ との関連 ${ }^{3), 5)}$ で考察されている。

著者はこのPSPを人間工学的実験を行っている 時に軀幹筋である筒柱起立筋において偶然観察し た (図 1参照)。その際PSP の機能的意義に大変 な興味を感じた。PSPが上位中枢性の現象であれ ば、負荷強度を動作発現前に被験者に知らせるこ とによって出現頻度および持続時間 (筋放電消失 期間）に変化が起るかもしれないと考えた。この ことを調べるために筹柱起立筋に弱い持続性放電 が出現する伸膝立位前屈姿勢から急激な腰部伸展 動作を自発的に行わせ、腰部伸展と同時に台上の 錘（外的負荷）を引き上げさせた場合と外的負荷 無しの場合における出現頻度および持続時間を比 較した。動作発現準備期における脊柱起立筋の活 動レベルは $10 \%$ と同じであるのに、外的負荷有り 条件に打ける出現頻度は外的負荷無し条件に打忛 るよりも高く、持続時間も延長した。また外的負 荷重量の増加は出現頻度をさらに高め、持続時間 もより長くなった。これらの結果からPSPは動作 発現と同時に腰部に急激に加わる負荷の大きさに 抗する筋収縮制御のされ方の影響を受けたとみる ことができ、PSP は筋収縮速度とだけよりも、む しろ力強くて速い筋収縮と関係があるらしいこと が示唆された。随意動作を素速く行ら際、反応時 間動作におけるH波が示しているように動作に先 行して主衝筋の春䯣 $\alpha$ 運動ニューロンの促通が起 る ことは理解できてる、抑制を受けるのは運動 ニューロンの発火間値の点から考兄て不利である。 PSPの出現は必ずしも筋収縮速度だけに依存する とはいえないようである。 
2.2 持続性筋放電様相の変化 ${ }^{8)}$

上記のPSPの出現頻度等を調べた実験において 相動性放電に先行してPSPではなく鋸歯状の筫電 図波形が記録された。この鋸歯状の波形の等電図 ピーク（鋸に例えると、1つ1つの歯の先端にあた る）とピークの時間間隔は 20〜30 msec でリズミ カルな波形であった。このため鋸歯状の筋電図は rhythmic slower wave(RSW) と名付けられた。 脊柱起立筋に怙ける RSW の出現样相を前回の実 験と同じ姿勢および動作条件で調べた結果、RSW の出現頻度が高い被験者のPSP の出現頻度は低く 逆にRSW の出現頻度の低い被験者のPSP出現頻 度は高かった。図1はRSW の代表的記録である。

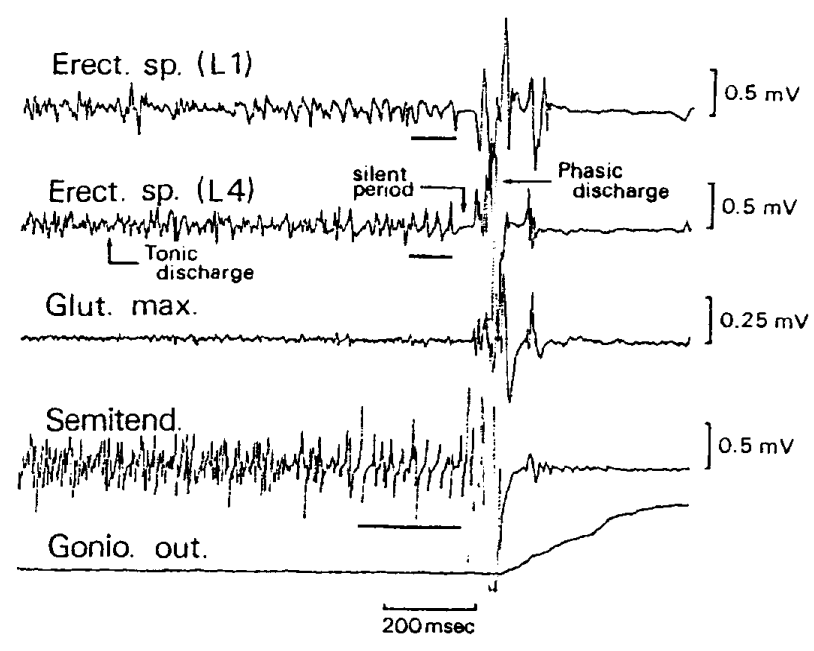

図 1 運動発現準備期における持続性筋放電の rhythmic slower wave(フンダーライン) ヘの変化

PSPは時々RSWに続いて出現した。第 1 および 第 4 腰椎レベルの脊柱起立筋の RSW の発生は動 作の $200 \mathrm{msec}$ 前であった。半腱様筋における RS $\mathrm{W}$ の出現は明瞭で、その出現は動作の $320 \mathrm{msec}$ 前であった。このほか RSWが動作の 300〜 450m $\sec$ 前に出現することもあった。 RSW の出現時間 はRSWが運動隼備と関連があるらしいことを示 唆している。

半腱様筋の PSPが脊柱起立筋のそれよりも数 10 msec遅れて出現したり、PSP が耐柱起立笳に出 現しても半腱様筋に出現しないことがあった。こ れらの結果からPSPが资髄全体の同時抑制による
という考え ${ }^{3)}$ に疑問が生じる。

\subsection{RSW 出現中の運動単位活動 ${ }^{9)}$}

RSW出現中に運動単位 $(M U)$ 活動の変化が実 際に起っているかが、反応合図に応じた腰伸展動 作に㧧いて調べられた。

図2はRSWが反応合図の前に振幅の増加を伴 って出現した記録である。RSWの振幅はその後反 応合図の $125 \mathrm{msec}$ 前に減少した。振幅減少前の筋 電図ピークの出現間隔は 20〜30 msec と規則的で あるけれども、振幅減少と共にこの規則性は乱れ た。これらの筋電図ピークはMUの同期性放電と 時間的に一致していた。RSWの反応合図前の出現 は運動準備と関連した現象であることを暗示して いる。針筋電図の基線付近の background dischargeが RSW の出現中堿少した。図 3 は相動性 放電の前に拈ける持続性放電の種々の変化を示し ている。RSWの出現と同時に background discharge が消失し、PSP 出現時には針電極からの電 位もサイレントであった。

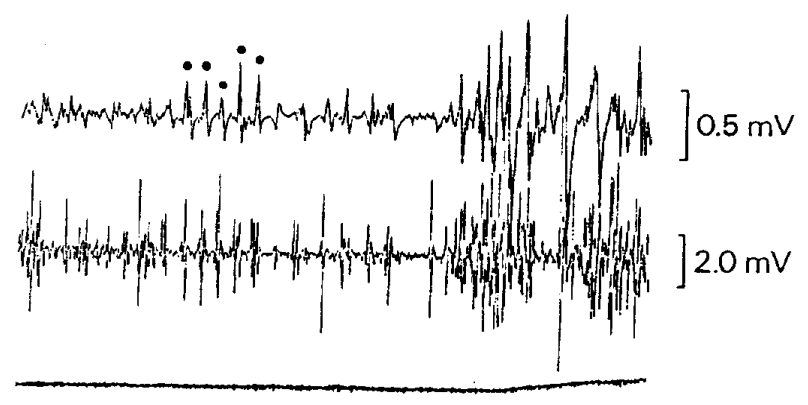
S2

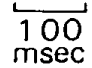

図 2 Rhythmic slower waveの筋電図ピーク (黒丸) と運動単位の同期性放電の時間 的一致。

最上段：表面筋電図、二段目：針筋電図、 三段目：股関節角度計の出力、最下段： 反応合図 (S2)。

background dischargeに関する結果は RSW 出現中の MU 活動の減少を示唆しており、図 3 は $\mathrm{RSW}$ とPSPは同じメカニズムで説明される抑制 
現象である可能性を示している。メカニズムのス ペキュレーションとして反回性抑制とこの抑制機 構を構成する Renshaw 細胞の上位中枢性制御機 構が考兄られる。このスペキュレーションは文献 番号 9 番の論文に記述されている。

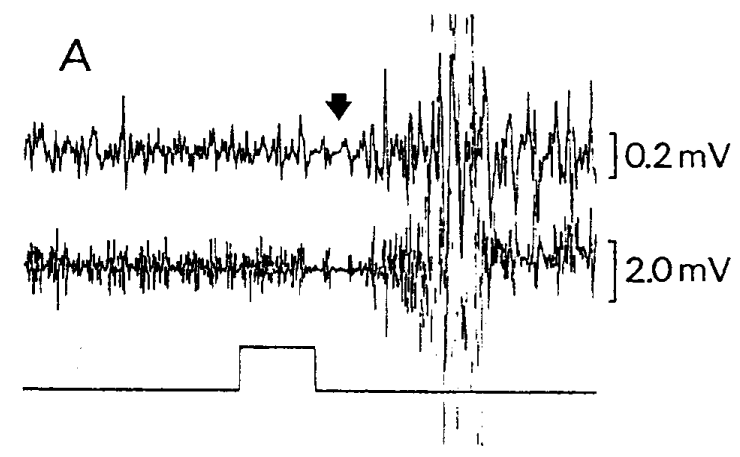

\section{B}
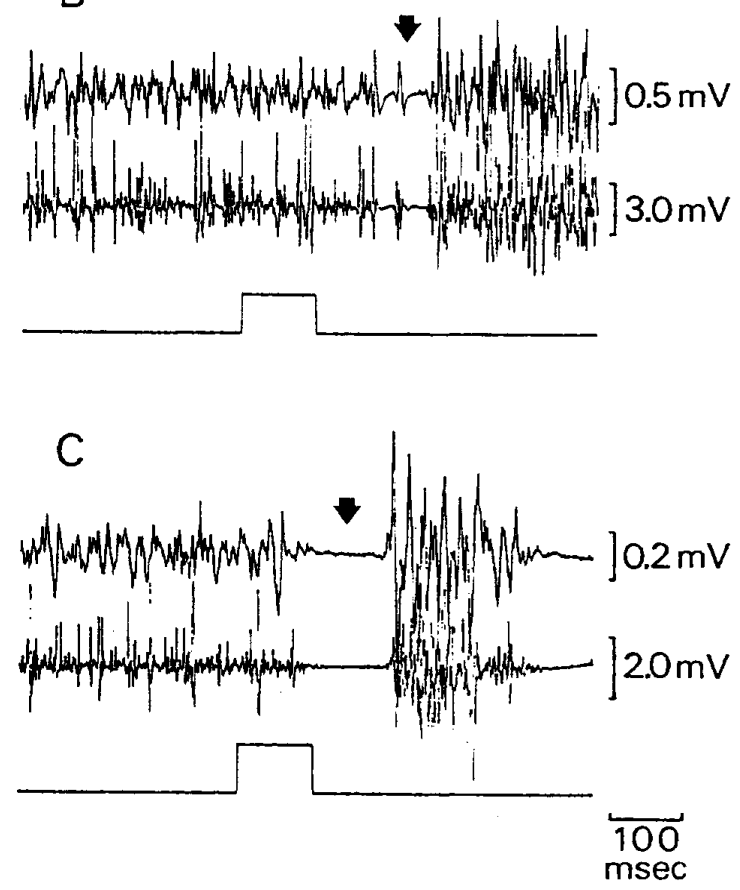

図 3 相動性筋放電に先行する表面筋電図の変 化 (矢印)

AはRSW、BはRSWに続いて出現した PSP、CはPSPを表している。

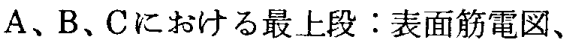
中段：針筋電図、最下段：反応合図。

\section{4 周波数分析 $^{10)}$}

運動発現準備期においてRSW が観察されなく ても、運動発現の準備的構えが表面筋電図の周波 数成分に影響する可能性が考えられる。このこと
を検討するために、反応動作における予告合図か ら反応合図までの 2 秒間の表面筋電図の平均周波 数と予告合図前の 2 秒間のそれとの比較を行った。

予告合図後の平均周波数は予告合図前の平均周 波数のそれよりも数值的に小さく、予告合図前後 の平均周波数の差の検定を行った結果、統計的に 有意差が認められた。これらの結果は予告合図後 に表面筋電図の質的変化、すなわち低周波数化 (slowing) が起ったことを示唆している。

以上のいくつかの実験から得られた結果はRSW およびPSPが随意運動の準備・開始と関連した特 別な中枢神経活動を反映した末梢性の現象である ことを示している。

\section{RSW およびPSP と運動関連脳電位構成 成分の関係 ${ }^{11}$}

自発性運動に前後する脳電位全体を運動関連脳 電位と総称し、先行寸る部分は運動前脳電位と呼 ばれる。運動前脳電位は運動に先行して $0.8 \sim 1$ 秒 前に始まり、負電位として緩徐に增大寸る。その 後運動の約 0.5 秒前から電位振幅の増加勾配が急 峻になる。 を示す 1 つの指標とされている。そこで運動前の 持続性放電の変化が運動準備・開始と関係がある といらょり一層の証拠を得るために、RSW と PS $\mathrm{P}$ が運動前脳電位と時間的にいかに関連するかの 検討が行われた。

運動は右肘伸展力の素速い発揮で自発的に行わ れた。運動発現の準備期間中、最大肘伸展力の 20 $\%$ 水準の筋力が保持された。この状況における主 働筋は右上腕三頭筋で、準備期においてはこの筋 から小さい振幅の持続性放電が記録された。脳波 を国際 10-20法に基づき、C3 (左脳半球側)、CZ (頭頂)、C4 (右脳半球側) から記録し、表面筋電 図と共に加算平均した。加算回数は50回であった。

実験中に記録した生データの視診を行った結果、 RSW のほかに表面筋電图の slowing が観察され た。これらの筋電図の変化は脳波の陰性変動を伴 った。加算平均された運動前脳電位は勾配の異な る3つの陰性電位成分に分かれた (図 4)。最初の 電位 (FNP) は相動性放電の約 1 秒前に出現した。 
2番目の電位 (SNP) は相動性放電の 330〜 510m $\mathrm{sec}$ 前に始まり、RSW 等の筋電圀変化の多くはこ のSNP相に扣いて起った。PSPは相動性放電の $30 \sim 60 \mathrm{msec}$ 前に始まった 3 番目の電位 (TNP) の出現中に出現した。図 4 における相動性放電の 出現の前に扣ける持続性放電の振幅の減少は PSP のためである。3つの運動前脳電位の振幅は CZで 最も大きく、また運動肢と同側におけるよりも反 対側において電位の振幅は大きかった。左右半球 における電位振幅の非対称性はSNPおよびTNP 相において統計的に有意であった。このことは、 SNP、TNPは運動と密接に関連した電位であるこ とを意味しており、RSW等の筋電図変化および $\mathrm{P}$ $\mathrm{SP}$ は随意運動の準備・開始と関連があると結論で きる。

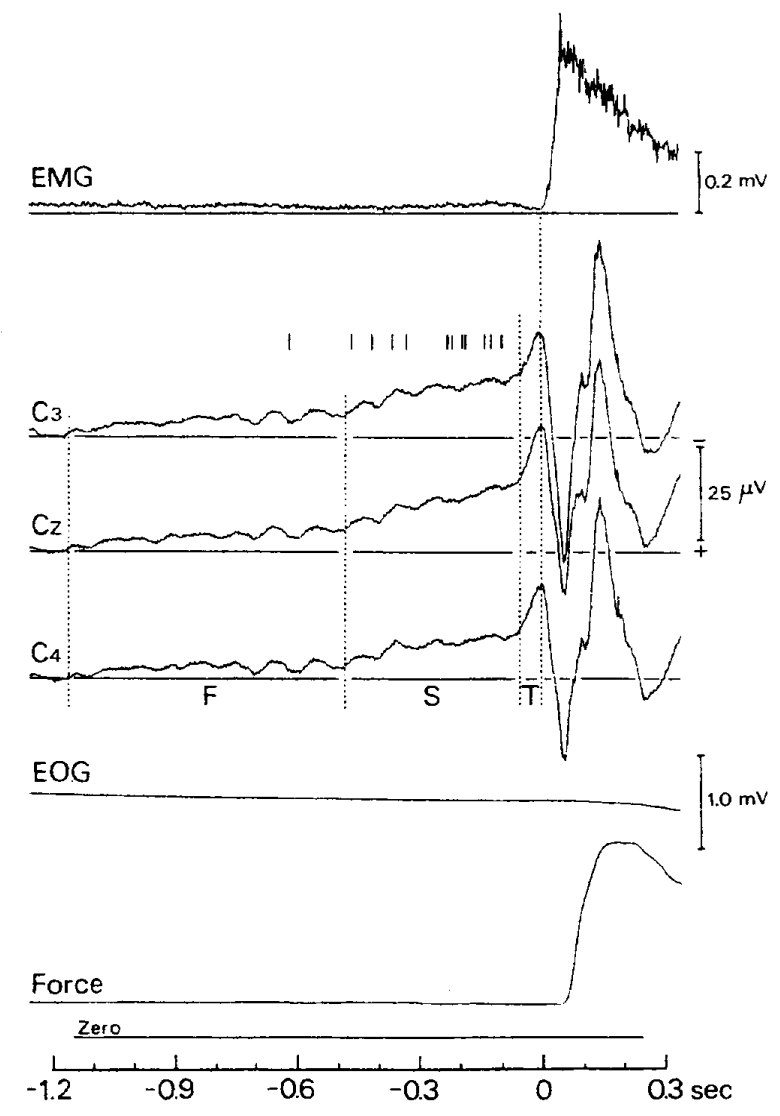

図 4 自発性の急激な右肘伸展力発揮運動にお いて記録された代表的な運動関連脳電位。 $\mathrm{F}: \mathrm{FNP}, \mathrm{S}: \mathrm{SNP}, \mathrm{T}: \mathrm{TNP}$ C 3 で測定された脳電位の上の縦棒は slower waveの出現時間を示している。 時間軸 0 秒は相動性筋放電の出現時点で ある。
加算平均された相動性放電の出現からピークに 達するまでの時間は、TNPが観察されなかった被 験者に拈けるよりも観察された被験者に打いてよ り短く、筋力が発揮されてからピークに達するま での時間も同様に TNP 出現者においてより短かか った。TNPは抢そらく相電性放電の急峻な立ち上 がりをもたらす皮質脊髄路の興奮活動を反映し、前 述したPSPの機能的役割と同様に速くて力強い筋 収縮と関連しているとみることができる。PSPの 出現頻度はTNP出現者に打いてより高かった。随 意収縮が急速に行われた際の張力の上昇は、個々 のMUの発射頻度の一過性增加に上りもたらされ ることが知られている。 活動に影響するのかもしれない。

RSW、PSPは抑制現象であり、SNP、TNP は 興奮現象であると思われるけれども、PSPの出現 頻度とTNPの関係およびRSW、PSP とSNP、T NPの出現時間関係から、RSW、PSPの出現メカ ニズムはSNP、TNPを生み出すメカニズムと上位 中枢に扣いて密接に結合しているということが推 察される。Renshaw 細胞はいくつかの運動中枢、 例えば運動皮質から強い興奮性扣よび抑制性制御 を受けることが知られている。

この実験に抢いて興味深いことは、TNPの機能 的意義が一連の研究の初期に考察されたPSPの機 能的役割と一致することを示唆するデータが得ら れたことである。

\section{4. 運動関連脊郤電位 ${ }^{15)}$}

次に RSW およびPSPが上位中枢性の抑制現象 であることを非侵襲的に脊髄レベルでみることが できないかに興味が持たれた。ヒトの随意運動に 伴う $\alpha$ 運動ニューロンの興奮・抑制の情報を非侵 襲的に得上うとする場合、電気剌激によって得ら れる $\mathrm{H}$ 波の記録が行われる。しかしながら、この 手法を自発性運動に颃いて運動関連脳電位を測定 する実験には使用することはできない。電気剌激 が脳波に影響することと、運動発現の時点を検者 は予測できないからである。そこで脊柱部の背部 皮膚上に表面電極を配置し、単極導出法によって 記録を試みた。当初記録することができるならば 
運動関連脳電位と同様に陰性の緩電位であるだろ らと考光、時定数を 3.0 秒に設定した。記録電極 を頸部に配置した場合、基準電極がぞこの部位で あっても心電図の混入があり、しかも時定数 3.0 秒では心電図波形のらねりが大きいために電位の 同定は困難であった。それゆえ 0.1 秒以下の時定 数を使って実験を続けた。最近、産医大・神経内 科の过貞俊先生のご指導をいただけたこともあっ て、間違いなくレスポンスであるだろらというデ 一タを得ることができた。持続性筋放電を生じさ せる予備緊張を実験条件にした実験はこれからの ため、ここでは予備緊張なしの条件で得られた結 果を報告する。

自発性運動として右上腕三頭筋を主働筋とする 时伸展力発揮を選び、発揮筋力の水準を中程度と した。上腕三頭笳を支配する橈骨神経は第 6 第 8 頸椎の椎間孔から出た後、鎖骨の後下、上肢 腋窩を通り上記の筋に達する。橈骨神経は上腕神 経叢の1つの枝である。導出法は前述したよらに 単極導出法で、記録電極を第 6 頸椎棘㔖起部皮膚 上に置いた。このほかにェルブ点にも記録電極を 貼付した。腕神経叢は鎖骨の上方 $2 \sim 3 \mathrm{~cm}$ に位置す るエルブ点の下を通っており、この点を電気刺激 すると上腕の諸筋から筋電図を記録することがで さる。上記 $2 つ の$ 記録電極に対する基準電極を左 膝蓋骨部皮膚上に貼付した。実験中、左膝を非活 性にするために両足を足首の位置で組ませ、筋力 発揮に下肢が関与しないよらにした。脳波を頭頂 から、表面筋電図を右上腕三頭筋から導出した。 頸部脊髄電位およびェルブ点電位は時定数 0.1 , 0.03,0.01秒で増幅された。これらの電位の記録に は心電図の混入があったため、心電図の $\mathrm{R}$ 波と $\mathrm{R}$ 波の間の休止期に運動が発現された試行における データだけを加算平均処理の対象とした。

図 5 は代表的な加算平均結果で、同一被験者か ら測定日を変えて得られたデータを線の太さを違 えて重ね書きしたものである。頸部およびェルブ 点から記録された電位の波形の形態は、時定数お。 よび測定日が異なってもよく類似している。頸部 電位およびェルブ点電位は共に相動性放電の出現 前に始まる陰性電位として出現し、相動性放電の
出現後に陰性ピークに達した後、陽性電位へ移行 し、陽性ピークに達した。運動関連脳電位の第 3 成分であるTNPが相動性放電の前に観察される (図 5、矢印)。

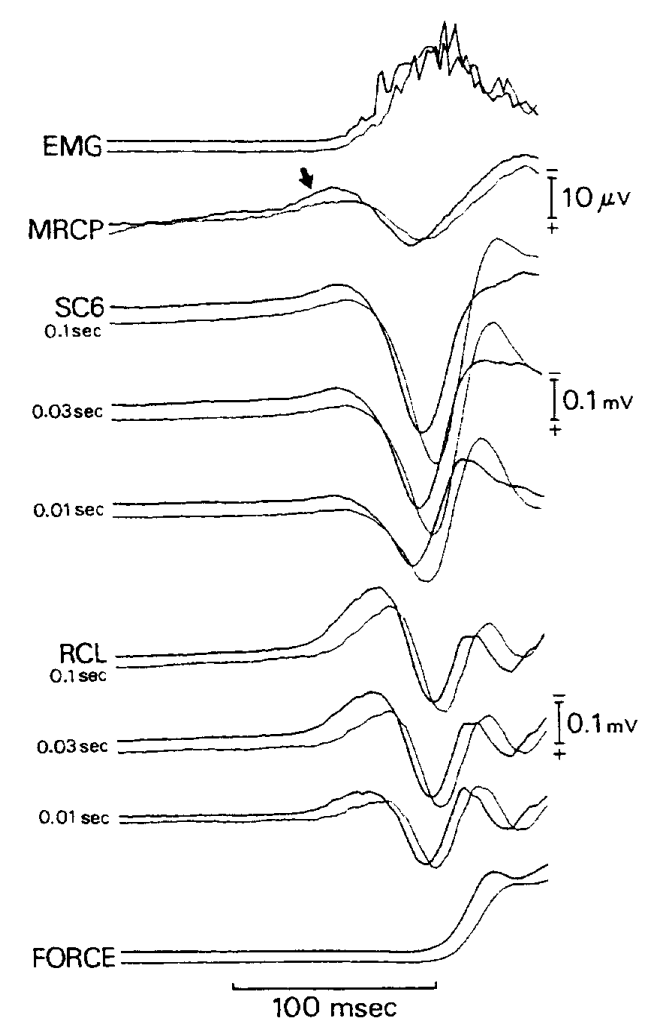

図 5 運動関連脊髄・エルブ点電位の代表的記録 $\mathrm{EMG}$ : 表面筋電図、MRCP : 運動関連脳電位 SC 6 :第 6頸椎棘突起部から記録された電位 RCL : 右エルブ点から記録された電位

表 1 は相動性放電の出現を基準とした際の陰性 ピークと陽性ピークの潜時を示している。Subj. KT とSubj. IWについては 4 回実験が行われたけ れども、同一被験者内に怙ける数值はかなり近似 している。残り 5 人の被験者から得られた数値も また、Subj. IMの陽性ピーク潜時を除いて、前記 の 2 人から得られた数値と大きく異らない。陰性 ピークおよび陽性ピークの潜時は、Subj. AIの陽 性ピーク潜時の結果を除いて、いずれも頸部にお。 いてェルブ点におけるよりも短かかった。

陰性ピークと陽性ピークの時間間隔は、表 1 か らうかがえるように、頸部電位およびェルブ点電 位共に個人内变動および個人差は少なかった。

上肢自発性運動に扣いて記録された陰性電位お 
よび陽性電位がアーティファクト等であれば、測 定日および時定数が異なった場合、波形の形態は 全く異なり、ピーク出現潜時および陰性と陽性の ピーク時間間隔もかなりばらつくはずである。し かしながら再現性のあることを示すデータが得ら れたことは、運動と関連した電位を頸部皮膚上お よびェルブ点から表皮上記録することができるこ とを示唆している。頸部から記録された電位の起 源は頸髄レベルのどこかとしかいえないけれども エルブ点電位の起源は上腕神経叢に由来している と考えられる。

頸部およびエルブ点から記録された陰性電位の 出現位置はPSPが出現する位置である。それゆ古、 予備緊張状態から自発性運動を急激に発現させて PSPを出現させた際、上記陰性電位の消失むしく は振幅の減少が起るかどうかは興味深く、消失等 が起れば、この実験で同定された陰性および陽性 電位はレスポンスであり、PSPは抑制現象である ことを示す1つの証拠になると思われる。

表 1 相動性筋放電の出現を基準とした際の第 6 頸椎棘突起部 (SC6) 扣よびエルブ点 (RCL) から記録された陰性および陽性電位ピーク の潜時

\begin{tabular}{lccccc}
\hline Subject & \multicolumn{2}{c}{$\begin{array}{c}\text { Negative peak } \\
\text { latency } \\
\text { (msec) }\end{array}$} & & \multicolumn{2}{c}{$\begin{array}{c}\text { Positive peak } \\
\text { latency } \\
\text { (msec) }\end{array}$} \\
\cline { 2 - 3 } \cline { 5 - 6 } & SC 6 & RCL & & SC 6 & RCL \\
\hline Subj. KT & 12 & 24 & & 52 & 56 \\
& 9 & 27 & & 54 & 57 \\
& 5 & 17 & & 52 & 56 \\
& 9 & 23 & & 49 & 53 \\
Subj. IW & 25 & 31 & & 53 & 69 \\
& 18 & 26 & & 46 & 58 \\
& 23 & 31 & & 52 & 85 \\
Subj. NO & 2 & 18 & & 42 & 46 \\
Subj. NS & 21 & 30 & & 53 & 57 \\
Subj. SA & 13 & 25 & & 50 & 52 \\
Subj. AI & 12 & 19 & & 56 & 46 \\
Subj. IM & 18 & 24 & & 83 & 85 \\
\hline Mean & 14.7 & 25.0 & 53.1 & 60.8 \\
S. D. \pm & 7.4 & 4.9 & & 9.7 & 12.9 \\
\hline
\end{tabular}

文献

1) 谷井克則：急速な腰のばし動作に先行して脊柱起 立筋に出現する Electromyographic silent period, 人類学雑誌、91, 11-24(1983)

2）猪飼道夫：動作に先行する抑制機構、日本生理誌、 17, 292-298(1955)

3）矢部京之助、村地俊二：随意動作に先行する silent periodの役割、日本生理誌、37，91-98(1975)

4) Yabe, K. : Premotion silent period in voluntary rapid movement, J. Appl. Physiol., 41, 470-473 (1976)

5) 川初清典：身体運動における巧及さの科学、杏林 書院 (1982)

6）猪飼道夫・他：随意動作に先行する silent period の発現機構、体育学研究、18,127-133(1973)

7) Shimoyama, M. \& Tanaka, R. : Reciprocal Ia inhibition at the onset of voluntary movements in man, Brain Res., 82, 334-337(1974)

8) Tanii, K. : Occurrence of a rhythmic slower wave in EMG prior to a rapid voluntary movement, Electroenceph. clin. Neurophysiol., 57, 435440(1984)

9) Tanii, K. \& Kinugasa, T. : Changes in activity of motor units preceding a rapid voluntary movement, Electroenceph. Clin. Neurophysiol., $63,188-191(1986)$

10) Tanii, K. et al. : Power spectral analysis of the surface electromyogram before and after a warning signal in a reaction movement, Electroenceph. Clin. Neurophysiol., 60, 532538(1985)

11) Tanii, K. et al. : Temporal relationships of EMG changes preceding voluntary movement to premovement cortical potential shifts, Electroenceph. Clin. Neurophysiol., 67, 412420(1987)

12) Shibasaki, H. et al. : Components of the movement-related cortical potential and their scalp topography, Electroenceph. Clin. Neurophysiol., 49, 213-226(1980)

13) Tanji, J. \& Kato, M.: Discharges of single motor units at voluntary contraction of abductor digiti minimi muscle in man, Brain Res., 45, 590-593(1972)

14) Haase, J. et al. : Problems of postsynaptic autogenous and recurrent inhibition in the mammalian spinal cord, Rev. Physiol. Biochem. Pharmacol., 73, 73-129(1975) 
15）谷井克則、辻貞俊：随意運動と関連した脊髄電位 および Erb点電位の表皮上記録、脳波と筋電困、 $17,168(1989)$

谷井克則（たにいかつのり）昭和 44 年東京教育大学 大学院体育学研究科修士課程修了、昭和 44 年 工業技 術院産業工芸試験所 (現在の製品科学研究所) 意匠第 一部人間工学課研究員、昭和 52 年工業技術院製品科 学研究所人間工学部人間工学第一課主任研究官、現在、 製品科学研究所基礎人間工学部生理情報工学課主任研 究官。主に筋負担等疲労の評価、作業姿勢の負担評価、 筋運動制御に関する研究等に従事。昭和 52 年 (財) 労 働科学研究所から桐原賞を受賞。日本人間工学会評議 員、日本産業衛生学会、日本体力医学会、日本脳波筋 電図学会、人類働態学会の会員。 